\title{
TECHNICAL AND ECONOMIC ANALYSIS OF IRRIGATION OF ASPARAGUS BEAN IN PROTECTED ENVIRONMENT
}

\author{
WELLINGTON G. SILVA ${ }^{2}$, JACINTO A. CARVALHO ${ }^{3}$, EDUARDO C. OLIVEIRA ${ }^{4}$, \\ JOAQUIM A. LIMA JÚNIOR ${ }^{5}$, BUNO M. SILVA $^{6}$
}

\begin{abstract}
This experiment was conducted in Lavras - state of Minas Gerais (MG), Brazil, in a protected environment, and aims to estimate the irrigation depths that maximize productivity and economic returns in the cultivation of asparagus bean and analyze the economic viability of irrigation management. The experimental delineation was randomized blocks with five treatments and four replications. The treatments consisted of five drip irrigation depths: 40, 70, 100, 130 and $160 \%$ of water replacement depth up to field capacity. The depths of water that maximize productivity and economic returns were obtained from the regression model adjusted to productivity data, cost of product relations and water cost. The economic viability was achieved on the benefit/cost ratio basis. The depth with the maximum economic return was estimated in $434.4 \mathrm{~mm}$, with a productivity of $35,160.6 \mathrm{~kg} \mathrm{ha}^{-1}$, which is economically viable for the cultivation of asparagus bean, with a expected profitability of R 1.70 for every real invested.
\end{abstract}

KEYWORDS: Vigna unguiculata spp. sesquipedalis, irrigation management, economic viability, benefit/cost ratio.

\section{ANÁLISE TÉCNICA E ECONÔMICA DA IRRIGAÇÃO DO FEIJÃO-DE-METRO EM AMBIENTE PROTEGIDO}

RESUMO: O experimento foi conduzido em Lavras-MG, e teve como objetivo avaliar, técnica e economicamente, o efeito de diferentes lâminas de irrigação aplicadas por gotejamento na produtividade do feijão-de-metro. O delineamento experimental foi em blocos casualizados, com cinco tratamentos e quatro repetições. Os tratamentos constituíram-se de cinco lâminas de irrigação por gotejamento, sendo: 40; 70; 100; 130 e 160 \% da lâmina de reposição de água até a capacidade de campo. As lâminas de água que maximizam a produtividade e o retorno econômico foram obtidas a partir do modelo de regressão em função de dados de produtividade, das relações de preço do produto e do custo da água. A viabilidade econômica foi obtida com base na relação benefício/custo. A lâmina de máximo retorno econômico foi estimada em 431,3 mm, com uma produtividade de $35.156,6 \mathrm{~kg} \mathrm{ha}^{-1}$, que é viável economicamente para o cultivo do feijão-de-metro, com uma rentabilidade esperada de $\mathrm{R} \$ 1,7$ para cada real investido.

PALAVRAS-CHAVE: Vigna unguiculata spp. sesquipedalis, manejo de irrigação, viabilidade econômica, relação benefício/custo.

\section{INTRODUCTION}

The asparagus bean (Vigna unguiculata spp. sesquipedalis, L.) is an annual climbing plant, and produces long pods (0.5 to $1.0 \mathrm{~m}$ ) harvested still in the immature stage (XU et al., 2011). It is tolerant to high temperatures and acid soils (FLYMAN \& AFOLAYAN, 2008).

\footnotetext{
${ }^{1}$ Extraído da tese de doutorado do primeiro autor.

${ }^{2}$ Engo . Agrônomo, DSc., Faculdade de Ciências Agrárias (FCA/UFAM), Departamento de Engenharia Agrícola e Solos, wellington@ufam.edu.br.

${ }^{3}$ Engo. Agrícola, Prof. DSc., Departamento de Engenharia (DEG/UFLA), jacintoc@deg.ufla.br.

${ }^{4}$ Eng $^{0}$. Agrícola, DSc., Departamento de Engenharia (DEG/UFLA), eduardoco@oi.com.br.

${ }^{5}$ Eng $^{\circ}$. Agrônomo, Prof. DSc., Departamento de Ciências Exatas e Engenharia (DCEE/UFRA), Joaquim.junior@ufra.edu.br.

${ }^{6}$ Eng $^{\circ}$. Agrônomo, Doutorando, Departamento de Ciência do Solo (DCS/UFLA), bmontoani@hotmail.com.

Recebido pelo Conselho Editorial em: 18-10-2011

Aprovado pelo Conselho Editorial em: 24-1-2013
} 
This vegetable is an important source of minerals and protein in the diet of the inhabitants of Southeast Asia, India and western China (CHEN et al., 2007; FLYMAN \& AFOLAYAN, 2008).

In Brazil, especially in the North, the asparagus bean assumes social and economic importance; it is grown by small farmers who produce for both consumption and commercial scale. The production of this vegetable is seasonal, therefore excess rain is harmful to the culture, and the production is concentrated mainly at the end of the rainy season, when farmers take advantage of the natural moisture of the floodplain areas (CARDOSO, 1997).

Given this fact, it is necessary to search for alternatives that allow the stability of the offer of agricultural products and promote income generation, as the irrigation and cultivation in protected environment (MAGGI et al., 2006; DERMITAS \& AYAS, 2009).

As the focus of farmers is profit, to make a decision whether or not to adopt new crop alternatives, it is necessary to analyze the financial results to be derived from the investment of resources. Therefore, it is essential to obtain information from the return on invested capital.

The combination of production factors to adjust the return of irrigated crops in economically appropriate levels can be obtained by using mathematical models to predict the productive response of plants to water application (MONTEIRO et al., 2006; MACIEL et al., 2007, OLIVEIRA et al., 2011). These models, known as "water-culture production function", are extensively used in studies of economic analysis. The use of these models is justified by the need to find an indicator of character agrieconomic without resorting to complex methods and difficult operation.

Researchers conducted with different cultures have shown that the second-degree polynomial is usually used to describe the production function in economic analysis of agricultural research (KOETZ et al., 2008; VILAS BOAS et al., 2008; BILIBIO et al. 2010).

Therefore, through this study, it was evaluated technically and economically the effect of different irrigation depths applied by drip in the productivity of asparagus bean in a protected environment.

\section{MATERIAL AND METHODS}

The experiment was conducted in a greenhouse at the experimental area of the Department of Engineering of the Federal University of Lavras (UFLA), in Lavras - state of Minas Gerais (MG), Brazil, according to geographical coordinates: $21^{\circ} 13^{\prime} 48^{\prime \prime} \mathrm{S}, 44^{\circ} 58^{\prime} 36^{\prime \prime} \mathrm{W}$ and $903 \mathrm{~m}$. The soil was classified as Distroferric Red Latosol (EMBRAPA, 2006), its texture is loamy to layer 0-30 cm, whose physical and chemical characteristics can be seen in Table 1 . During the experiment the temperature and the relative humidity of the air were $27.9^{\circ} \mathrm{C}$ and $65.2 \%$, respectively.

The greenhouse consists of wooden pillars (treated eucalyptus); ceiling with metal frame in the shape of arch - covered with transparent polyethylene film, anti-UV additive, with a thickness of $150 \mu \mathrm{m}$, and sides closed with clarite mesh. It has $2.5 \mathrm{~m}$ of ceiling height, $4 \mathrm{~m}$ tall at its highest point, $15 \mathrm{~m}$ long and $6 \mathrm{~m}$ wide.

TABLE 1. Soil physical and chemical characteristics in the experimental area, at the 0-30cm layer*.

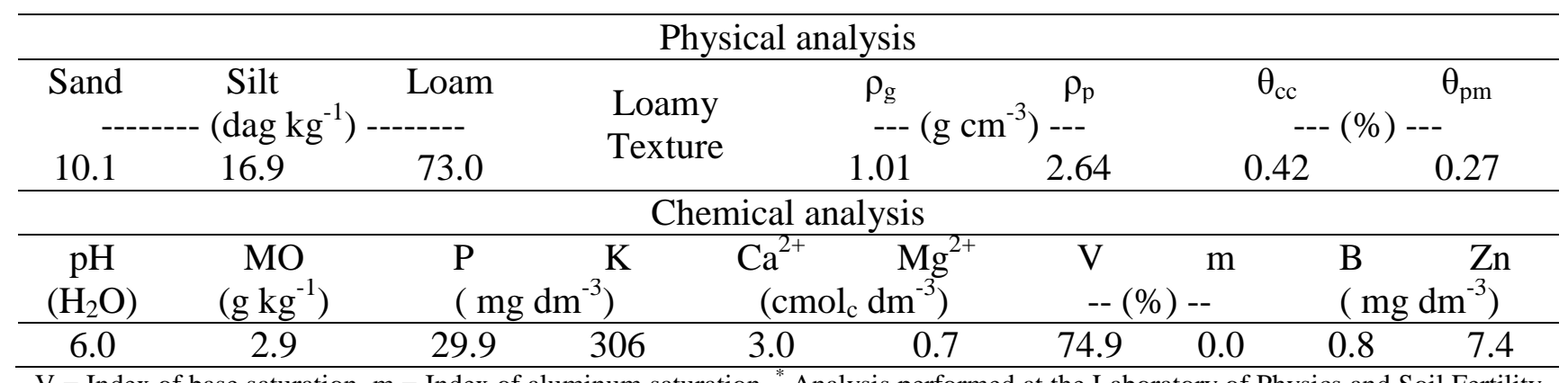

$\mathrm{V}=$ Index of base saturation, $\mathrm{m}=$ Index of aluminum saturation. ${ }^{*}$ Analysis performed at the Laboratory of Physics and Soil Fertility of the DCS/UFLA 
The characteristic curve of the soil water retention was experimentally obtained. The values were adjusted to the model VAN GENUCHTEN (1980). With the help of the computer program SWRC 3.0 (Soil Water Retention Curve), developed by DOURADO NETO et al. (2000), it was obtained the equation 1 with coefficient of adjustment of 0.98 :

$$
\theta=0,260+\frac{0,355}{\left[1+(0,2079|\psi|)^{2,0279}\right]^{0,5069}}
$$

In which,

$\theta$ - soil moisture $\left(\mathrm{cm}^{3} \mathrm{~cm}^{-3}\right)$, and

$\psi$ - matric potential $(\mathrm{kPa})$.

The experimental delineation was in randomized blocks with five treatments and four replications. The treatments were applied based on the different levels of replacement of water in the soil, that is, $\mathrm{T}_{1}, \mathrm{~T}_{2}, \mathrm{~T}_{3}, \mathrm{~T}_{4}$ and $\mathrm{T}_{5}$ corresponding respectively to $40 \%, 70 \%, 100 \%, 130 \%$ and $160 \%$ of control treatment $\left(\mathrm{T}_{3}-100 \%\right.$ of replacement of water to raise the soil moisture at field capacity). Each experimental unit consisted of a plat with a line of planting of two meters length and density of six plants per meter. It was considered the 10 central plants as useful.

The plats were internally delimited by a black polyethylene film (with a thickness of 0.03 $\mathrm{mm}$ ), with the aim of preventing the movement of water between them and to not interfere with treatments, they were constructed with $2.0 \mathrm{~m}$ length, $0,40 \mathrm{~m}$ wide, $0.30 \mathrm{~m}$ deep, and spaced at $0.40 \mathrm{~m}$ in the longitudinal direction and $0.60 \mathrm{~m}$ in the transverse direction. The soil used in the plats was air dried, dragged in $4 \mathrm{~mm}$ mesh sieve and homogenized.

The fertilization of planting and cover were made according to the analysis of soil fertility and recommendations to the bean pod culture (CARRIJO et al, 1999). A total of $150 \mathrm{~kg} \mathrm{ha}^{-1}$ of N and $230 \mathrm{~kg} \mathrm{ha}^{-1}$ of $\mathrm{P}_{2} \mathrm{O}_{5}$ was used. The planting fertilization was made during the preparation of the soil, adding the entire contents of $\mathrm{P}_{2} \mathrm{O}_{5}$. Part of the fertilizer with $\mathrm{N}$ was made on the day of sowing (30\%) and the remainder (70\%) was divided into two applications performed at 25 and 40 days after emergence (DAE). The nutrient sources used were urea and triple superphosphate.

The cultivar used was the "brown seed." 36 seeds were sown per plat, distributed in 12 furrows at $1.0 \mathrm{~cm}$ depth (10/01/2009). The germination occurred on 10/05/2009 (when 100\% of the seedlings had emerged), date when the differentiation of treatments began. Three days after emergence (10/08/2009) the lopping was done leaving 12 plants (conducted in espalier system, with the last wire at $1.8 \mathrm{~m}$ height above the ground). To ensure the germination of the seeds was applied a total of $75 \mathrm{~mm}$ of water in all treatments parceled in three irrigations of $25 \mathrm{~mm}$, at intervals of one day.

The irrigation was performed by drip. It was used in each plat six auto-compensating drippers spaced at $0.33 \mathrm{~m}$, with a flow rate of $4 \mathrm{~L} \mathrm{~h}^{-1}$ and an operating pressure of $100 \mathrm{kPa}$. The average uniformity of water application was $99.1 \%$, obtained after assembly the irrigation system.

The irrigation management was performed from reading the matric potential observed in four tensiometers installed at $0.15 \mathrm{~m}$ depth at the experimental treatment units of replacement of $100 \%$ of water depth $\left(\mathrm{T}_{3}\right)$. The readings were performed every morning (at 9, 12, 15 and 17 hours) using a digital tensiometer with a sensitivity of $0.1 \mathrm{kPa}$.

At the time of each irrigation when tensiometers average matric potential reached $15 \mathrm{kPa}$, the volumetric water content, associated as matric potential, was used to calculate the irrigation to be applied in the treatment $\mathrm{T}_{3}$ (aiming to raise the humidity of the soil of field capacity to a depth of 0.30) (Table 1). In other treatments, the depths corresponded to the percentage applied for each treatment. It is noteworthy that the application of different water depths was performed varying the time of irrigation treatments. 
The harvest of the pods was done during 26 days (57-82 DAE), performed 12 days after anthesis, when the pods passed the intense dark green to bright light green (harvest point).

The results were statistically evaluated by analysis of second-degree polynomial regression. The adjusted regression model was chosen based on the significance of the regression coefficients $(\mathrm{P}<0.05)$ and the coefficient of determination $\mathrm{R}^{2}$. Statistical tests were performed with the help of statistical software SISVAR version 5.0 (FERREIRA, 2008).

The production function used for the economic analysis was obtained from the regression model adjusted for productivity data, represented by the equation 2 :

$$
\mathrm{Y}_{\mathrm{e}}\left(\mathrm{W}_{\mathrm{i}}\right)=\mathrm{B}_{0}+\mathrm{B}_{1} \mathrm{~W}_{\mathrm{i}}+\mathrm{B}_{2} \mathrm{~W}_{\mathrm{i}}^{2}
$$

In which,

$\mathrm{Y}_{\mathrm{e}}\left(\mathrm{W}_{\mathrm{i}}\right)$ - estimated productivity, $\mathrm{kg} \mathrm{ha}^{-1}$;

$\mathrm{W}_{\mathrm{i}}$ - applied water depth, $\mathrm{mm}$, and

$\mathrm{B}_{0}, \mathrm{~B}_{1}$ and $\mathrm{B}_{2}-$ coefficients of regression, with hypothesis in which $\mathrm{B}_{1}>0$ and $\mathrm{B}_{2}<0$.

The total cost of production (TC, R\$ ha ${ }^{-1}$ ) can be divided in fixed costs (FC, R\$ ha ${ }^{-1}$ ) and variable costs (VC, $\mathrm{R} \$ \mathrm{ha}^{-1}$ ). The fixed costs are those that occur independent of the number of hours of operation of the irrigation system $\left(\mathrm{R} \$ \mathrm{ha}^{-1}\right)$, in the considered analysis term. To obtain these costs it was used the equations 3,4 e 5 :

$$
\begin{aligned}
& \mathrm{TC}=\mathrm{FC}+\mathrm{VC} \\
& \mathrm{FC}=\mathrm{C}_{\mathrm{p}}+\mathrm{C}_{\mathrm{fi}} \\
& \mathrm{VC}=\mathrm{C}_{\mathrm{w}} \cdot \mathrm{W}_{\mathrm{i}}
\end{aligned}
$$

In which,

$\mathrm{C}_{\mathrm{p}}$ - production of the culture cost, $\mathrm{R} \$ \mathrm{ha}^{-1}$;

$\mathrm{C}_{\mathrm{fi}}$ - fixed cost of irrigation, $\mathrm{R} \$ \mathrm{ha}^{-1}$, and

$\mathrm{C}_{\mathrm{w}}-$ cost of water irrigation, $\mathrm{R} \$ \mathrm{~mm} \mathrm{ha}^{-1}$.

The cost of production of the culture (Cp), without considering the costs of applying water depth, according to the survey of prices in the local market, in October 2009, was R\$ 17,839.6 ha $^{-1}$. In the cost of production structure of this study was considered the expenses related to the cost of land and administration (BACH \& LOPES, 2007). It was add to these expenses a portion of fixed costs represented by the depreciation of durable goods used in the production process (protected environment).

To calculate the fixed and variable costs related to the irrigation it was considered a system of drip irrigation to attend the following characteristics: irrigated area of 1 ha, total manometric height of 50m; flow of the pumping unit of $11.8 \mathrm{~m}^{3} \mathrm{ha}^{-1} \mathrm{~h}^{-1}$; yield of the motopump set of $50 \%$, and 4 daily hours of operation. Under these conditions, the cost of the irrigation system according to the information obtained from companies of project and commercialization of irrigation equipment was $\mathrm{R} \$$ 9,960.48 and includes all works required for the operation.

To calculate the fixed cost of irrigation $\left(\mathrm{C}_{\mathrm{fi}}, \mathrm{R} \$ \mathrm{ha}^{-1}\right)$ was used the capital recovery factor (CRF), which provides a coefficient that allows, from the investment value, calculate the fixed cost related to this investment. Thus, the $\mathrm{C}_{\mathrm{fi}}$ was of $\mathrm{R} \$ 587.62 \mathrm{ha}^{-1}$ cycle $^{-1}$, which was calculated using the equations 6 and 07:

$$
\mathrm{C}_{\mathrm{fi}}=\frac{\mathrm{CFR} \cdot \mathrm{S}_{\mathrm{i}}}{\mathrm{n}}
$$




$$
\operatorname{CFR}=\frac{\mathrm{j} \cdot(1+\mathrm{j})^{\mathrm{uv}}}{(1+\mathrm{j})^{\mathrm{uv}}-1}
$$

In which,

$\mathrm{j}$ - annual interest rate, 0.12;

uv - useful life of the irrigation system, 10 years.

$\mathrm{S}_{\mathrm{i}}$ - irrigation system cost; and

$\mathrm{n}$ - number of culture cycles per year, 3 .

By the current model of water management, the cost of water irrigation can be considered zero. However for purposes of economic analysis this cost was obtained based on the cost of electricity used for pumping $\left(\mathrm{C}_{\mathrm{EE}}, \mathrm{R} \$ \mathrm{~mm}^{-1}\right)$ and the cost of maintenance and operation of the irrigation system $\left(C_{m o}, R \$ m^{-1}\right)$, obtained in December 2009. Assuming that small farms fits within the consumer class B2 (BILIBIO et al., 2010) the cost of water $\left(C_{w}\right)$ was calculated by equations 8, 9 and 10. Thus, $\mathrm{C}_{\mathrm{w}}$ was of $\mathrm{R} \$ 2.02 \mathrm{~mm}^{-1} \mathrm{ha}^{-1}$.

$$
\begin{aligned}
& \mathrm{C}_{\mathrm{w}}=\mathrm{C}_{\mathrm{EE}}+\mathrm{C}_{\mathrm{mo}} \\
& \mathrm{C}_{\mathrm{EE}}=\frac{10 \cdot \mathrm{H} \cdot 0,736 \cdot \mathrm{T}_{\mathrm{e}} \cdot \mathrm{L}_{\mathrm{R} 100 \%}}{270 \cdot \eta} \\
& \mathrm{C}_{\mathrm{mo}}=\frac{0,02 \cdot \mathrm{S}_{\mathrm{i}}}{\mathrm{n}}
\end{aligned}
$$

In which,

$\mathrm{H}$ - manometric height, m;

$\mathrm{T}_{\mathrm{e}}$ - electric energy tariff, $0,68 \mathrm{R} \$ \mathrm{kWh}^{-1}$;

$\mathrm{L}_{\mathrm{R} 100 \%}$ - water depth applied in the treatment with replacement of $100 \%$, mm;

$\eta$ - yield of the motopumping set, decimal.

The water depth to be applied to obtain maximum productivity $\left(\mathrm{W}_{\mathrm{m}}\right)$ was calculated by deriving the total physical product (given by equation 2) in relation to the variable factor and equating to the derivative obtained to zero. At this point the total physical product is maximum. Thus:

$$
\mathrm{W}_{\mathrm{m}}=-\frac{\mathrm{B}_{1}}{2 \mathrm{~B}_{2}}
$$

The irrigation management strategy to be adopted should reflect on maximizing economic return (profit). This point is reached when equals the first derivative of Equation 2 in relation to $\mathrm{W}$ to the ratio between the cost of water factor $\left(\mathrm{C}_{\mathrm{w}}\right)$ and the price of the product $\left(\mathrm{P}_{\mathrm{y}}\right)$, obtaining the equation of optimum economic depth $\left(\mathrm{W}^{*}\right)$ :

$$
\mathrm{W}^{*}=\mathrm{W}_{\mathrm{m}}+\frac{\mathrm{C}_{\mathrm{w}}}{2 \mathrm{~B}_{2} \mathrm{P}_{\mathrm{y}}}
$$

In which,

$\mathrm{C}_{\mathrm{w}}-$ cost of the water factor, $\mathrm{R} \$ \mathrm{~mm}^{-1}$, and

$\mathrm{P}_{\mathrm{y}}$ - price of the product, $\mathrm{R} \$ \mathrm{~kg}^{-1}$.

The net revenue (NR, $\mathrm{R} \$ \mathrm{ha}^{-1}$ ) was obtained by the difference between the gross revenue (GR, $\mathrm{R} \$ \mathrm{ha}^{-1}$ ) and the total cost (TC), as the equation:

$$
\begin{aligned}
& \mathrm{NR}_{\mathrm{wi}}=\mathrm{GR}-\mathrm{TC} \\
& \mathrm{GR}=\mathrm{P}_{\mathrm{y}} \cdot \mathrm{W}_{\mathrm{i}}
\end{aligned}
$$


The analysis of the economic viability of irrigation of the asparagus bean was based on the benefits of its adoption and on the investments and costs of implementation, using the profitability index of the benefit/cost ratio $(\mathrm{B} / \mathrm{C})$. As a criterion for decision making it was considered the minimum value above 1 , and therefore the ratio $\mathrm{B} / \mathrm{C}$ should overcome this value for the activity to be considered economically viable (ARAÚJO et al., 2011). This indicator was quantified using Equation 15.

$$
\mathrm{B} / \mathrm{C}=\frac{\mathrm{GR}}{\mathrm{TC}}
$$

\section{RESULTS AND DISCUSSION}

The values of irrigation depths applied during the experiment are presented in table 2. It is noted that the applied total depth (WT) does not correspond to the levels of replacement initially set for the respective treatments, unlike the depth applied after the differentiation treatment $\left(\mathrm{W}_{\mathrm{it}}\right)$. This is due to the depth applied in the phase $\left(\mathrm{W}_{\text {ii) }}\right)$,used to ensure seed germination and plant establishment.

TABLE 2. Water depth in the initial phase $\left(\mathrm{W}_{\mathrm{ii}}\right)$, during treatment $\left(\mathrm{W}_{\mathrm{it}}\right)$ and total depth irrigation (WT).

\begin{tabular}{cccccc}
\hline \multirow{2}{*}{ Depth } & \multicolumn{5}{c}{ Treatments (\%) } \\
\cline { 2 - 6 } & 40 & 70 & 100 & 130 & 160 \\
\hline $\mathrm{W}_{\text {ii }}(\mathrm{mm})$ & 75 & 75 & 75 & 75 & 75 \\
$\mathrm{~W}_{\text {it }}(\mathrm{mm})$ & 124.8 & 218.9 & 312.1 & 405.7 & 499.4 \\
$\mathrm{WT}(\mathrm{mm})$ & 199.8 & 293.9 & 387.1 & 480.7 & 574.4 \\
\hline
\end{tabular}

The results of the analysis of variance and regression (Table 3) showed significant effect $(\mathrm{P}<0.05)$ for all variables (number of pods, fresh weight and production), indicating the dependence of the effects of the treatments used in the experiment. A similar response was obtained by OLIVEIRA et al. (2011), whose results were significant for yield and number of pods by applying $50,75,100,125$ and $150 \%$ of replacement of water consumed by the pea culture.

TABLE 3. Summary of variance and regression analysis related to asparagus bean pod number (PN), fresh weight (FW) and production (PP) according to the water depths applied.

\begin{tabular}{ccccc}
\hline \multirow{2}{*}{ Variation sources } & \multirow{2}{*}{ GL } & \multicolumn{3}{c}{ Quadratic mean } \\
\cline { 3 - 5 } & 1 & $271.72^{*}$ & $14.53^{*}$ & $100.549 .09^{*}$ \\
QM & 1 & $887.32^{*}$ & $0.73^{*}$ & $139.800 .04^{*}$ \\
SM & 2 & $48.41^{*}$ & $0.11^{*}$ & $6.968 .09^{*}$ \\
Deviation & 3 & $14.85^{*}$ & $0.32^{*}$ & $3.648 .35^{*}$ \\
Blocks & 12 & 11.56 & 0.07 & $2.093 .75^{*}$ \\
Residue & & 8.93 & 2.15 & 9.93 \\
\hline CV $(\%)$ & &
\end{tabular}

LM = Linear model; QM = Quadratic model; * = significative at 5\% of probability by the F test; CV = Coefficient of variation.

Regression analysis applied to the data (number, fresh weight and pod production in function of applied water depths) showed a significant difference for the linear and quadratic model (Table 3). Therefore, the model shown for setting the regression equation for all variables is quadratic (BANZATTO \& KRONKA, 2006). It is worth noting that the coefficients of determination of this model best represented, in proportion, the variation in the analyzed data as explained by the fitted equation (Table 4). SANTANA et al. (2009), planting common bean (Phaeseollus vulgaris L.) under five levels of water replacement (40, 70, 100, 130 and 160\%), also noted better fit of the data to the quadratic model. 
TABLE 4. Regression equations adjusted to asparagus bean pod number (PN), fresh weight (FW) and production (PP) data according to the water depths applied.

\begin{tabular}{ccc}
\hline Variables & Adjusted regression & $\mathrm{R}^{2}$ \\
\hline \multirow{2}{*}{ PN } & $\mathrm{y}=26.6497+0.0295^{*} \mathrm{~W}_{\mathrm{i}}$ & 0.23 \\
& $\mathrm{y}=-35.6210+0.3938^{*} \mathrm{~W}_{\mathrm{i}}-0.0005^{*} \mathrm{~W}_{\mathrm{i}}{ }^{*}$ & 0.94 \\
FW & $\mathrm{y}=9.45449+0.00650^{*} \mathrm{~W}_{\mathrm{i}}$ & 0.94 \\
& $\mathrm{y}=7.74159+0.01653^{*} \mathrm{~W}-0.00001^{*} \mathrm{~W}^{2}$ & 0.99 \\
PP & $\mathrm{y}=246.1735+0.5541^{*} \mathrm{~W}_{\mathrm{i}}$ & 0.40 \\
& $\mathrm{y}=-533.02+5.1135^{*} \mathrm{~W}_{\mathrm{i}}-0.0059^{*} \mathrm{~W}_{\mathrm{i}}{ }^{2}$ & 0.96 \\
\hline
\end{tabular}

Observing the results shown in Table 5, it was found that the number of pods and production increased by the application of the layer of $387.10 \mathrm{~mm}$, and then decrease. The volume of fresh weight of pods showed continued growth tendency as a result of applied water depths. The occurrence of drop in the number of pods and production by applying the depths upper and lower of $387.10 \mathrm{~mm}$ of water is due to, respectively, the deficit or the excess of water in which the asparagus bean plants were submitted during the experimental period.

TABLE 5. Values relative to the number (PN), fresh weight (NF) and production (PP) of asparagus bean pods according to water depths applied $\left(\mathrm{W}_{\mathrm{i}}\right)$.

\begin{tabular}{|c|c|c|c|}
\hline $\begin{array}{c}\mathrm{W}_{\mathrm{i}} \\
(\mathrm{mm})\end{array}$ & $\mathrm{PN}$ & $\begin{array}{l}\text { FW } \\
\text { (g) }\end{array}$ & $\begin{array}{c}\text { PP } \\
\left.\text { (g plant }^{-1}\right)\end{array}$ \\
\hline 198.8 & 24.0 & 10.6 & 255.2 \\
\hline 293.9 & 39.0 & 11.3 & 445.5 \\
\hline 387.1 & 49.0 & 12.3 & 599.5 \\
\hline 480.7 & 41.0 & 12.7 & 519.3 \\
\hline 574.4 & 37.0 & 12.9 & 472.3 \\
\hline
\end{tabular}

The best results for the number and production of pods were obtained with the application of the depth of $387.10 \mathrm{~mm}$ (100\% replacement), indicating that the application of deficit depths (198.8 and $293.9 \mathrm{~mm}$ ) and excessive depths $(480,7$ and $574.4 \mathrm{~mm}$ ) did not reach its maximum productive potential asparagus bean (Table 5). These results confirm the negative effects of improper management of irrigation in the literature (SANTANA et al., 2009, OLIVEIRA et al., 2011).

BILIBIO et al. (2010) obtained similar results studying the effect of water replacement depths (50, 75, 100, 125 and 150\%) in the cultivation of eggplant (Solanum melongena L.), noting that the highest yield was obtained with full replacement of water consumed. To fully restore the water depth to the ground the plants may increase the yield and thus express all their productive potential, since no other factor is limiting.

Similarly, KOETZ et al. (2008), testing the effect of four levels of water replacement depths (50, 75, 100 and 125\%), also observed higher yield of tomato (Solanum lycopersicum L.) with water depths which kept the soil moisture close to field capacity (100\% replacement). Replacement of water above and below this value resulted in lower performance.

The obtention of higher fresh weight of asparagus bean pod, harvested from plots cultivated with excessive depths (480.7 and $574.4 \mathrm{~mm}$ ), may be due to the reduced number of pods produced under these culture conditions (Table 5). With fewer pods on the plant the availability of nutrients and photoassimilates may have increased, which may have contributed to the gain in fresh weight.

Although there was an increase in fresh weight of pods with the increase of applied water depths, this was not enough to compensate the losses in yield of plants which produced fewer pods when grown under excessive depths (Table 5). However, what matters in asparagus bean is the 
number of pods, and on these facts, it can infer that the strategy for management of water irrigation to be adopted by the producer to increase productivity of asparagus bean should prioritize maximizing the number of pods and not just the increase in fresh weight of these.

According to the data reported in Table 6 for both variable costs and fixed costs, it was found higher average costs for lower yields and lower average costs for higher yields. This is due to greater dilution of costs between the highest yield (PINDYCK \& RUBINFELD, 2010), which reflects the use of more rational use of resources.

It can also be observed from Table 6 that the variable costs represented greater percentage of the total cost with the application of larger water depths. These results are due to the rising energy costs consumed for pumping, mainly because the higher the applied water depth is, the greatest number of hours of operation of the irrigation system.

TABLE 6. Mean variable cost (MVC), mean fixed cost (MFC) and mean total cost (MTC) of asparagus bean production according to the water depths applied $\left(\mathrm{W}_{\mathrm{i}}\right)$.

\begin{tabular}{ccccccc}
\hline $\begin{array}{c}\mathrm{W}_{\mathrm{i}} \\
(\mathrm{mm})\end{array}$ & $\begin{array}{c}\mathrm{PR} \\
\left(\mathrm{kg} \mathrm{ha}^{-1}\right)\end{array}$ & $\begin{array}{c}\text { MVC } \\
\left(\mathrm{R} \$ \mathrm{~kg}^{-1}\right)\end{array}$ & $\begin{array}{c}\text { MFC } \\
(\% \mathrm{MVC})\end{array}$ & $\left(\mathrm{R} \mathrm{kg}^{-1}\right)$ & $(\% \mathrm{MFC})$ & $\begin{array}{c}\text { MTC } \\
\left(\mathrm{R} \$ \mathrm{~kg}^{-1}\right)\end{array}$ \\
\hline 198.8 & $15,310.45$ & 0.0264 & 2.1 & 1.2036 & 97.9 & 1.2300 \\
293.9 & $26,727.05$ & 0.0223 & 3.1 & 0.6895 & 96.9 & 0.7117 \\
387.1 & $35,967.74$ & 0.0218 & 4.1 & 0.5123 & 95.9 & 0.5341 \\
480.7 & $31,157.98$ & 0.0305 & 5.0 & 0.5773 & 95.0 & 0.6078 \\
574.4 & $28,335.00$ & 0.0411 & 5.9 & 0.6516 & 94.1 & 0.6927 \\
\hline \multicolumn{2}{r}{} \\
\hline
\end{tabular}

Considering the sale price of the asparagus bean $\left(\mathrm{R} \$ 0,92 \mathrm{~kg}^{-1}\right)$ and the cost to produce $1 \mathrm{~kg}$ of this vegetable ( $\mathrm{R} \$ 1,23 \mathrm{~kg}^{-1}$ ), it was verified that conducting the irrigation management applying $198.8 \mathrm{~mm}$ of water during the growing season, the farmer would have a loss of approximately R\$ $0,32 \mathrm{~kg}^{-1}$, because the selling price would not pay the cost of production. Therefore, it would be uneconomical to produce under this condition of irrigation management.

Based on the yield data, it was obtained the production function by adjusting the quadratic model (equation 15), and from these results was calculated the maximum and optimal factors.

$$
\mathrm{Y}_{\mathrm{e}}=-31,980.1+306.8 \mathrm{~W}_{\mathrm{i}}-0.353 \mathrm{~W}_{\mathrm{i}}^{2} \quad \mathrm{R}^{2}=0.96
$$

From the quadratic model (equation 15$)$, the maximum yield $\left(\mathrm{W}_{\mathrm{m}}\right)$ can be achieved by applying $437.46 \mathrm{~mm}$ of water, and the corresponding estimated yield of 34.633,2 $\mathrm{kg} \mathrm{ha}^{-1}$. On the other hand, was obtained the optimum economic depth $\left(\mathrm{W}^{*}\right)$ with application of $434.92 \mathrm{~mm}$, and from this value, the estimated yield was of $34.629,8 \mathrm{~kg} \mathrm{ha}^{-1}$. It was verified that the depth $\mathrm{W}_{\mathrm{m}}$ and $\mathrm{W}^{*}$ are similar, a fact also observed for cultures of tomato (KOETZ et al., 2008), lettuce (SILVA et al., 2008; VILAS BOAS et al., 2008), beans (SANTANA et al., 2009), eggplant (BILIBIO et al., 2010) and pea (OLIVEIRA et al., 2011).

As it can be seen, the water savings by applying the depth that maximizes the economic return $\left(\mathrm{W}^{*}\right)$ is $3.1 \mathrm{~mm} \mathrm{ha}^{-1}$, and the financial benefit of $\mathrm{R} \$ 3.2 \mathrm{ha}^{-1}$ (Table 7), so the differences are small and irrelevant to cover the additional costs $\left(\mathrm{R} \$ 6.3 \mathrm{ha}^{-1}\right.$ ) when adopting the depth to get the maximum yield $\left(\mathrm{W}_{\mathrm{m}}\right)$. Thus, it can be inferred that the maximum economic return can be obtained adopting an irrigation management to maintain soil moisture near field capacity, i.e., in this study was $100 \%$ replacement.

The small difference observed between the water depth that obtained the best economic return $\left(\mathrm{W}^{*}\right)$ and the maximum yield $\left(\mathrm{W}_{\mathrm{m}}\right)$ is due to the relation between the cost to apply water $\left(\mathrm{C}_{\mathrm{w}}\right)$ and the product price $\left(\mathrm{P}_{\mathrm{y}}\right)$, as $\mathrm{W}^{*}$ depends on this relation (equation 12). Therefore, whenever there are 
changes in the product price $\left(\mathrm{P}_{\mathrm{y}}\right)$, paid to the producer, or in the cost of applied water $\left(\mathrm{C}_{\mathrm{w}}\right)$, there will be a change in the optimum economic depth $\left(\mathrm{W}^{*}\right)$.

TABLE 7. Economic performance analysis of the water depths that maximize the productivity $\left(\mathrm{W}_{\mathrm{m}}\right)$ and economic return $\left(\mathrm{W}^{*}\right)$ of the asparagus bean.

\begin{tabular}{ccccccc}
\hline & $\begin{array}{c}\mathrm{W}_{\mathrm{i}} \\
(\mathrm{mm})\end{array}$ & $\begin{array}{c}\mathrm{Y}_{\mathrm{e}} \\
\left(\mathrm{Kg} \mathrm{ha}^{-1}\right)\end{array}$ & $\mathrm{GR}$ & $\begin{array}{c}\mathrm{C}_{\mathrm{t}} \\
\left(\mathrm{R} \$ \mathrm{ha}^{-1}\right)\end{array}$ & -------- & $\mathrm{NR}$ \\
\hline $\mathrm{W}^{*}$ & 431.3 & 35.156 .6 & 31.859 .4 & 19.300 .0 & 12.559 .4 & 1.7 \\
$\mathrm{~W}_{\mathrm{m}}$ & 434.4 & 35.160 .3 & 31.862 .5 & 19.306 .3 & 12.556 .3 & 1.7 \\
\hline \multicolumn{2}{l}{$\mathrm{W}_{\mathrm{i}}=$ applied depth; $\mathrm{Y}_{\mathrm{e}}=$ estimated yield; $\mathrm{GR}$ = gross revenue; $\mathrm{C}_{\mathrm{t}}$ = total cost; $\mathrm{NR}=$ net revenue; B/C = benefit/cost relation. }
\end{tabular}

Thus, the lower the ratio $\mathrm{C}_{\mathrm{w}} / \mathrm{P}_{\mathrm{y}}$ more the depth $\mathrm{W}^{*}$ approximates to $\mathrm{W}_{\mathrm{m}}$ and, consequently, the less water saving by adopting the management to apply $\mathrm{W}^{*}$ in relation to $\mathrm{W}_{\mathrm{m}}$. This shows that the optimum economic prices will depend on the time of the economic analysis.

It was observed from Table 7 that the economic return $\left(\mathrm{R} \$ 12,559.4 \mathrm{ha}^{-1}\right)$ applied to $\mathrm{W}^{*}$ is quite close ( $\mathrm{R} \$ 12,556.3 \mathrm{ha}^{-1}$ ) than that obtained with the application of $\mathrm{W}_{\mathrm{m}}$. This result demonstrates that the depth of maximum economic return $\left(\mathrm{W}^{*}\right)$ is similar to the one that provides maximum productivity $\left(\mathrm{W}_{\mathrm{m}}\right)$. Similar results have been observed in research conducted with different cultures (BILIBIO et al., 2010, OLIVEIRA et al., 2011; SANTANA et al., 2009).

The profitability indicator (B/C) was of 1.7 to $\mathrm{W}^{*}$ and $\mathrm{W}_{\mathrm{m}}$ (Table 7 ). This value indicates that for every real invested, the return will be of $\mathrm{R} \$ 1.7$. The indicator shows, based on the decision criteria $(\mathrm{B} / \mathrm{C}>1.0)$, economic viability of cultivation of asparagus bean for these irrigation management strategies.

\section{CONCLUSIONS}

To achieve the maximum productivity and economic return, the irrigation should be performed in order to keep the soil at field capacity;

It is economically viable the irrigation of asparagus bean in a protected environment, in view of the profitability of $\mathrm{R} \$ 1.7$ for each real applied in the investment.

\section{REFERENCES}

ARAÚJO, A. P. B.; COSTA, R. N. T.; LACERDA, C. F.; GHEYI, H. R. Análise econômica do processo de recuperação de um solo sódico no Perímetro Irrigado Curu-Pentecoste, CE. Revista brasileira de engenharia agrícola e ambiental, Campina Grande, v. 15, n. 4, p. 377-382, 2011.

BACH, D. B; LOPES, M. A. Estudo da viabilidade econômica do cultivo da babosa (Aloe vera L.). Ciência e Agrotecnologia, Lavras, v. 31, p.1.136-1.144, 2007.

BANZATTO, D. A.; KRONKA, S. N. Experimentação agrícola. 4.ed. Jaboticabal: FUNEP, 2006. $237 \mathrm{p}$.

BILIBIO, C.; CARVALHO, J. A.; MARTINS, M.; RESENDE, F. C.; FREITAS, W. A.; GOMES, L. A. A. Função de produção da berinjela irrigada em ambiente protegido. Irriga, Botucatu, v. 15, n. 1, p. 10-22, jan./mar., 2010.

CARDOSO, M.O. Hortaliças não-convencionais da Amazônia. Brasília: EMBRAPA, 1997. 152 p.

CARRIJO, I. V.; FILGUEIRA, F. A. R.; TRANI, P. E. Feijão-Vagem (trepador). In: RIBEIRO, A. C.; GUIMARÃES, P. T. G.; ALVAREZ V. V. H. (Ed.). Recomendações para uso de corretivos e fertilizantes em Minas Gerais. 5 ed. Lavras: UFV, 1999. p. 170. 
CHEN, C.; TAO, C.; PENG, H.; DING, Y. Genetic analysis of salt stress responses in asparagus bean (vigna unguiculata (L.) ssp. sesquipedalis verdc.). Journal of Heredity, Hubei, v. 98, n.7, p. 655-665, nov./dec. 2007.

DERMITAS, C.; AYAS, S. Deficit irrigation effects on pepper (Capsicum annuum L. Demre) yield in unheated greenhouse condition. Journal of Food, Agricultural and Environment, Helsink, v. 7, n. 3-4, p. 989-1003, jul./oct. 2009.

DOURADO NETO, D. ; NIELSEN, D. R. ; HOPMANS, J. W. ; REICHARDT, K. ; BACCHI, O. O. S. Software to model soil water retention curves (SWRC, version 2.00). Scientia Agricola, Piracicaba, v. 57, n. 1, p. 191-192, jan./mar. 2000.

EMBRAPA. Empresa Brasileira de Pesquisa Agropecuária. Sistema brasileiro de classificação de solos. Rio de Janeiro, 2006. 306 p.

FERREIRA, D. F. SISVAR: um programa para análises e ensino de estatística. Revista Symposium, Lavras, v. 6, n. 1, p. 36-41, jan./jun. 2008.

FLYMAN, M. V.; AFOLAYAN, A. J. Effect of plant maturity on the mineral content of the leaves of momordica balsamina (L). and Vigna unguiculata subsp. sesquipedalis (L.). Journal of Food Quality, Fort Hare, v. 31, n. 5, p. 661-671, oct. 2008.

KOETZ, M.; COELHO, G.; CARVALHO, J. A.; SOUZA, R. J.; SILVA, R. A. Produção do meloeiro em ambiente protegido irrigado com diferentes lâminas de água. Irriga, Botucatu, v. 11, n. 4, p. 500-506, out./dez. 2006.

KOETZ, M.; MASCA, M. G. C. C.; CARNEIRO, L. C.; RAGAGNIN, V. A.; SENA JUNIOR, D. G.; GOMES FILHO, R.R. Produção de tomate industrial sob irrigação por gotejamento no sudeste de Goiás. Revista Brasileira de Agricultura Irrigada, Fortaleza, v. 2, n. 1, p. 09-15, 2008.

MAGGI, M. F.; KLAR, A. E.; JADOSKI, C. J.; ANDRADE, A. R. S. Produção de variedades de alface sob diferentes potenciais de água no solo. Irriga, Botucatu, v. 11, n. 3, p. 415-427, jul./set. 2006.

MACIEL, J. L.; DANTAS NETO, J.; FERNANDES, P. D. Resposta da goiabeira à lâmina de água e à adubação nitrogenada. Revista brasileira de engenharia agrícola e ambiental, Campina Grande, v. 11, n. 6, p. 571-577, 2007.

MONTEIRO, R. O. C.; COLARES, D. S.; COSTA, R. N. T.; LEÃO, M. C. S.; AGUIAR, J. V. Função de resposta do meloeiro a diferentes lâminas de irrigação e doses de nitrogênio. Horticicultura Brasileira, Brasília, v. 24, n. 4, p. 455-459, out./dez. 2006.

OLIVEIRA, E. C.; CARVALHO, J. A.; RESENDE, F. C.; FREITAS, W. A. Viabilidade técnica e econômica da produção de ervilha (Pisum sativum L.) cultivada sob diferentes lâminas de irrigação. Engenharia Agrícola, Jaboticabal, v. 31, n. 2, p. 324-333, mar./abr., 2011.

PINDYCK, R. S.; RUBINFELD, D. L. Microeconomia. 7. ed. São Paulo: Pearson Education do Brasil, 2010.647 p.

SANTANA, M. J.; CARVALHO, J. A.; ANDRADE, M. J. B.; GERVÁSIO, G. G.; BRAGA, J. C.; LEPRI, E. B. Viabilidade técnica e econômica da aplicação de água na cultura do feijoeiro comum (Phaseolus vulgaris L.). Ciência e Agrotecnologia, Lavras, v. 33, n. 2, p. 532-538, mar./abr. 2009.

SILVA, P. A. M.; PEREIRA, G. M.; REIS, R. P.; LIMA, L. A.; TAVEIRA, J. H. S. Função de resposta da alface americana aos níveis de água e adubação nitrogenada. Ciência e agrotecnologia, Lavras, v. 32, n. 4, 1276-1281, jul./ago. 2008.

VAN GENUCHTEN, M. T. A closed form equation for predicting the hydraulic conductivity of insaturated soils. Soil Science Society of American Journal, Madison, v. 44, n. 5, p. 892-898, 1980. 
VILAS BOAS, R. C.; CARVALHO, J. A.; GOMES, L. A. A.; SOUZA, A. M. G.; RODRIGUES, R. C.; SOUZA, K. J. Avaliação técnica e econômica da produção de duas cultivares de alface tipo crespa em função de lâminas de irrigação. Ciência e agrotecnologia, Lavras, v. 32, n. 2, p. 525531, mar./abr. 2008.

XU, P.; WU, X.; WANG, B.; LIU, Y.; EHLERS, J. D. A SNP and SSR based genetic map of asparagus bean (Vigna. unguiculata ssp. sesquipedialis) and comparison with the broader species. Plos One journal, Kingdon, v. 6, n. 1, p. 1-8, jan. 2011. 